\title{
Enhancing the Effectiveness of Oxygen Evolution Reaction by Electrodeposition of Transition Metal Nanoparticles on Nickel Foam Material
}

\author{
Mateusz Łuba ${ }^{1}\left(\mathbb{D}\right.$, Tomasz Mikołajczyk ${ }^{1, *} \mathbb{D}$, Mateusz Kuczyński ${ }^{1}$, Bogusław Pierożyński ${ }^{1, *}$ \\ and Ireneusz M. Kowalski ${ }^{2}$
}

check for

updates

Citation: Łuba, M.; Mikołajczyk, T.; Kuczyński, M.; Pierożyński, B.;

Kowalski, I.M. Enhancing the

Effectiveness of Oxygen Evolution

Reaction by Electrodeposition of

Transition Metal Nanoparticles on

Nickel Foam Material. Catalysts 2021,

11, 468. https://doi.org/10.3390/

catal11040468

Academic Editor: Yongjun Feng

Received: 14 March 2021

Accepted: 1 April 2021

Published: 3 April 2021

Publisher's Note: MDPI stays neutral with regard to jurisdictional claims in published maps and institutional affiliations.

Copyright: (c) 2021 by the authors. Licensee MDPI, Basel, Switzerland. This article is an open access article distributed under the terms and conditions of the Creative Commons Attribution (CC BY) license (https:// creativecommons.org/licenses/by/ $4.0 /)$.
1 Department of Chemistry, Faculty of Agriculture and Forestry, University of Warmia and Mazury in Olsztyn, Plac Lodzki 4, 10-727 Olsztyn, Poland; mateusz.luba@uwm.edu.pl (M.Ł.); mateusz.kuczynski@uwm.edu.pl (M.K.)

2 Department of Rehabilitation, Faculty of Medical Sciences, University of Warmia and Mazury in Olsztyn, Zolnierska 14C Street, 10-561 Olsztyn, Poland; rehab@uwm.edu.pl

* Correspondence: tomasz.mikolajczyk@uwm.edu.pl (T.M.); bogpierozynski@yahoo.ca (B.P.); Tel.: +48-89-523-4177 (B.P.)

\begin{abstract}
Electrochemical oxygen evolution reaction (OER) activity was studied on nickel foam-based electrodes. The OER was investigated in $0.1 \mathrm{M} \mathrm{NaOH}$ solution at room temperature on as-received and Co- or Mo-modified Ni foam anodes. Corresponding values of charge-transfer resistance, exchange current-density for the OER and other electrochemical parameters for the examined $\mathrm{Ni}$ foam composites were recorded. The electrodeposition of Co or Mo on Ni foam base-materials resulted in a significant enhancement of the OER electrocatalytic activity. The quality and extent of $\mathrm{Co}$, and Mo electrodeposition on Ni foam were characterized by means of scanning electron microscopy (SEM) and energy-dispersive X-ray spectroscopy (EDX) analysis.
\end{abstract}

Keywords: oxygen evolution reaction; Ni foam; Co-modified Ni foam; Mo-modified Ni foam; electrodeposition; electrochemical impedance spectroscopy

\section{Introduction}

In recent years, the development of renewable energy sources has dramatically increased [1,2], resulting from both a gradual depletion of crude oil sources, as well as progressive degradation of the natural environment [3,4]. Unfortunately, currently-used green energy technologies are strongly dependent on weather conditions and topography. For instance, the energy production of solar panels reaches its peak value at noon; however, it does not meet the demands of energy consumption [5]. This phenomenon is well-known under the name of solar energy's duck curve. Appropriate storage of this energy excess could be the only solution to the above problem [6]. Currently, most of the produced renewable energy is stored in lithium-ion battery systems, because of their high-efficiency and convenience in exploitation. However, all batteries have their limitations, such as slow charge and discharge time, which is strongly dependent on ambient temperature, as well as limited operational lifetime. Moreover, used batteries could become environmentally important hazardous waste. One of the most promising new energy storage technologies is based on hydrogen generation by means of alkaline water electrolysis (AWE) $[7,8]$. Such produced hydrogen can be considered an entirely environmentally friendly energy carrier, since the only by-products generated during the hydrogen combustion are heat and water (see Equation (1)) [9].

$$
2 \mathrm{H}_{2}+\mathrm{O}_{2} \rightarrow 2 \mathrm{H}_{2} \mathrm{O}+Q
$$

While many catalysts are known to reduce the overpotential of hydrogen evolution reaction (HER), the more complex oxygen evolution (OER) process still requires a large 
amount of energy to proceed. Contrary to a comparatively fast single-electron transfer cathodic process, the OER is related to a slow and complex, four-electron transfer reaction (see Equation (2)) [10,11].

$$
4 \mathrm{OH}^{-} \rightarrow \mathrm{O}_{2}+2 \mathrm{H}_{2} \mathrm{O}+4 \mathrm{e}^{-}
$$

Hence, in order to minimize the overpotential of the OER, the researchers have made significant efforts in developing new types of anodes. As a result, electrodes based on ruthenium [12] and iridium [13] oxides were found to exhibit outstanding electrochemical properties towards the OER; however, because of their high costs, the use of these materials on the industrial scale is not economically practical. Therefore, in recent years, the researchers' attention has been shifted to more abundant and inexpensive transitional metals (Ni, Co, Mn, Mo, Fe) [14-16] and their alloys [17], oxides and carbides [18,19] to replace platinum group metals.

Thus, one of the most commonly used base materials to make electrodes, in the hydrogen production industry, are nickel and its derivatives. The employment of nickel and nickel-coated electrodes results from their unique properties, such as high catalytic activity in both hydrogen and oxygen evolution reactions. In addition, nickel exhibits superior anticorrosion properties in an alkaline environment. Generally, it is well-known that the OER on metals proceeds on the surface covered by their oxides, where nickel oxide/hydroxide species are especially catalytic in this reaction [20-26].

However, in order to compete with the electrocatalytic properties of electrodes based on noble metals, newly developed electrodes have to be characterized by large and highly active surface areas (HASA). Large values of HASA could be easily achieved by employing various materials, including foams, fibres, nanowires or nanocones. Such a base material could then be modified with a trace amount of transition metal(s) by one of the deposition methods (electrochemical, electroless, CVD: chemical vapour deposition or PVD: physical vapour deposition), which could further enhance the electrocatalytic properties of these innovative materials [20,21].

Nickel foam could be considered one of the most promising candidates for fabricating such a highly reactive anode in the process of the OER, as in addition to its unique electrocatalytic properties, $\mathrm{Ni}$ foam also provides large values of HASA. Nickel is also relatively inexpensive, compared to most noble metals [22].

In this work, electrochemically modified $\mathrm{Ni}$ foam materials were assessed as potential anodes towards the OER in alkaline $0.1 \mathrm{M} \mathrm{NaOH}$ environment through the employment of major electrochemical techniques. In addition, the structure and quality of electrodeposited Co and Mo on the surface of nickel foam were evaluated by means of a combined scanning electron microscopy (SEM) and energy-dispersive X-ray spectroscopy (EDX) methodology.

\section{Results and Discussion}

\subsection{SEM/EDX Characterization of Ni Foam and Co-, and Mo-Modified Nickel Foam Electrodes}

Figure 1a,b below illustrate SEM micrograph pictures of the electrodeposition effect of Co and Mo at small and trace amounts, respectively, on the Ni foam surface, recorded at the same magnification level. For the Co-modified Ni foam (at ca. 1 wt.\% Co), the surface of the base material is densely covered with a granular structure of small Co nuclei (see Figure 1a). On the other hand, a sample of Mo-modified Ni foam (at ca. 0.2 wt.\% Mo) is comparatively shown in a SEM micrograph picture of Figure $1 \mathrm{~b}$. The electrodeposited sample is covered with quite an irregular, amorphous and discontinuous structure through the Ni foam surface. In addition, the more detailed information on the composition of the prepared samples is shown in Table 1. Moreover, Figure 1c,d demonstrate the EDX pattern of Co- and Mo-modified Ni foam electrodes, respectively.

In addition, the SEM-approximated Co and Mo grain size value came to $50.0 \pm 3.5$ and $512 \pm 9.8 \mathrm{~nm}$, respectively. The above was performed through utilization of the Image Analysis Program (NIS-Elements Basic Research on Nikon). 

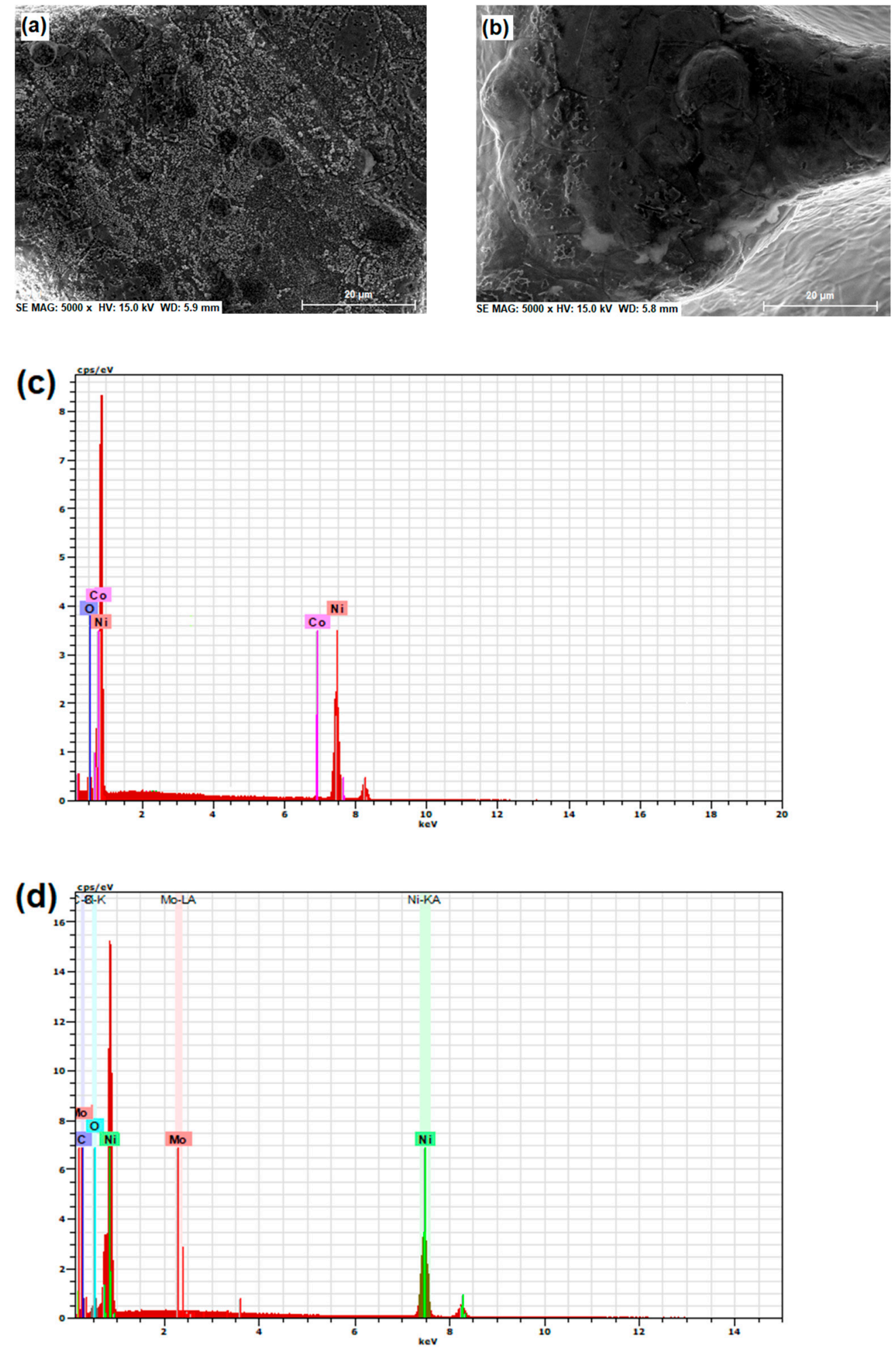

Figure 1. SEM micrograph pictures of Co-modified Ni foam surface (a), and Mo-activated Ni foam surface (b), taken at $5000 \times$ magnification with EDX pattern of Co- (c) and Mo-activated (d) Ni foam samples. 
Table 1. EDX-derived (for an acceleration voltage of $15 \mathrm{kV}$ ) chemical composition of surface elements for freshly prepared: Co- and Mo-modified Ni foam samples.

\begin{tabular}{cccc}
\hline & Element/\% & Spectrum 1 & Spectrum 2 \\
\hline Co-modified Ni foam & $\mathrm{Ni}$ & 95.83 & 92.84 \\
& $\mathrm{Co}$ & 1.06 & 1.25 \\
& $\mathrm{O}$ & 3.11 & 5.91 \\
& Total: & 100.00 & 100.00 \\
\hline \multirow{2}{*}{ Mo-modified Ni foam } & $\mathrm{Ni}$ & 92.08 & 86.42 \\
& $\mathrm{Mo}$ & 0.25 & 0.33 \\
& $\mathrm{O}$ & 2.61 & 5.06 \\
& $\mathrm{C}$ & 5.06 & 8.19 \\
& Total: & 100.00 & 100.00 \\
\hline
\end{tabular}

\subsection{OER Characterizations of Ni Foam, Co- and Mo-Modified Ni Foam Electrodes}

Cyclic voltammetry $(\mathrm{CV})$ characterization of the surface oxidation process on fresh, Co- and Mo-modified Ni foam electrodes in $0.1 \mathrm{M} \mathrm{NaOH}$ solution during $50 \mathrm{CV}$ sweeps, carried-out over the potential span 1.2-1.9 V/RHE (reversible hydrogen electrode) with a scan rate of $50 \mathrm{mV} \mathrm{s}^{-1}$ (only three last sweeps are presented) is shown in Figure 2 below. Thus, for pure and Co-modified nickel foam samples, the $\mathrm{CV}$ profiles displayed an oxidation peak (centred at ca. 1.49 and $1.45 \mathrm{~V}$, correspondingly) along with a cathodic reduction peak (starting around $1.3 \mathrm{~V}$ ). The Mo modification caused a shift of the oxidation peak to more positive potentials than that for pure $\mathrm{Ni}$ foam. In contrast, the reduction peak was no longer visible, as it was most likely moved outside the measured potential range. These features refer to the electrochemical formation of the surface $\beta-\mathrm{NiOOH}$ phase and its reduction to $\beta-\mathrm{Ni}(\mathrm{OH})_{2}$ layer, correspondingly (Equation (3)).

$$
\beta-\mathrm{Ni}(\mathrm{OH})_{2}+\mathrm{OH}^{-} \leftrightarrow \beta-\mathrm{NiOOH}+\mathrm{H}_{2} \mathrm{O}+\mathrm{e}^{-}
$$

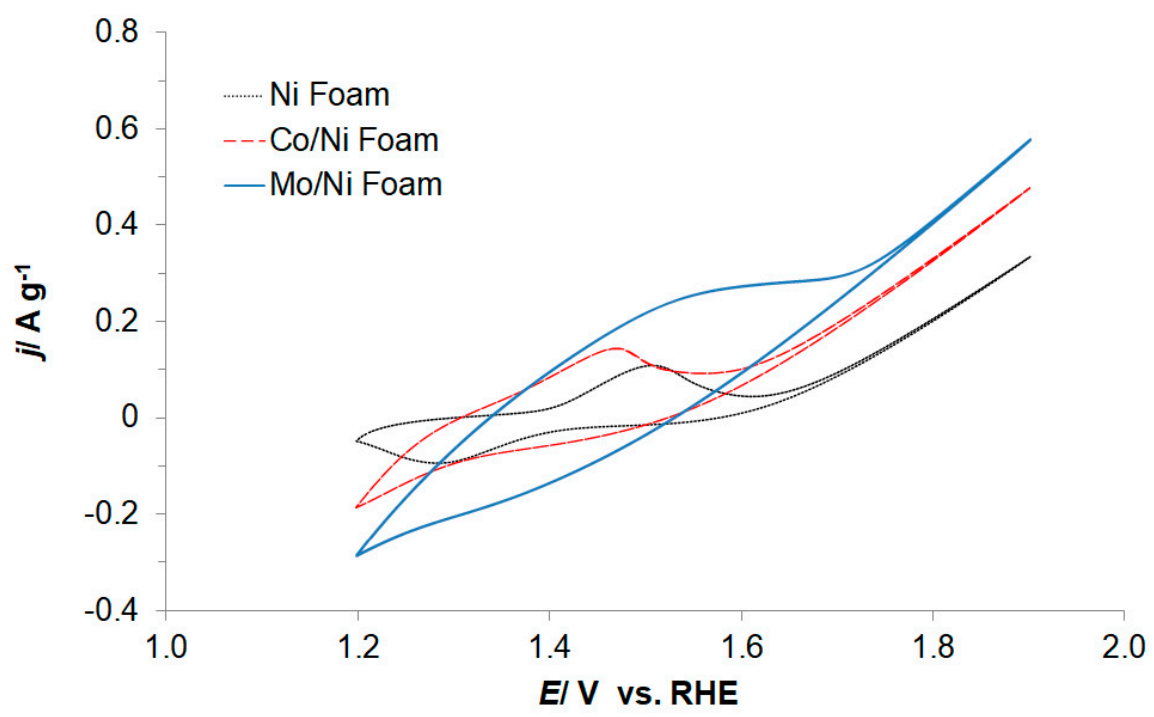

Figure 2. Cyclic voltammogram curves of oxidized, pure Ni, Co- and Mo-activated Ni foam electrodes, in contact with $0.1 \mathrm{M} \mathrm{NaOH}$ medium (at $20^{\circ} \mathrm{C}$ ), carried-out at a scan-rate of $50 \mathrm{mV} \mathrm{s}^{-1}$ for the potential span 1.2-1.9 V vs. RHE.

Tafel polarization plots recorded at room temperature for electrochemically oxidized, pure Ni foam, Mo- and Co-modified Ni foam electrodes are shown in Figure 3. Hence, for the nickel foam electrode, the recorded anodic Tafel slope (parameter $b_{\mathrm{a}}$ in Figure 3 ) and the Tafel-derived exchange current-density $\left(j_{0}\right)$ value for the OER came to $54 \mathrm{mV} \mathrm{dec}{ }^{-1}$ and $7.1 \times 10^{-11} \mathrm{~A} \mathrm{~cm}^{-2}$ over the low overpotential range. The modification utilizing 
surface Co or Mo deposition caused the values of $b_{\mathrm{a}}$ and $j_{0}$ parameters to rise to 83 and $74 \mathrm{mV} \mathrm{dec}^{-1}$, and $7.0 \times 10^{-8}$ and $9.6 \times 10^{-8} \mathrm{~A} \mathrm{~cm}^{-2}$, correspondingly, for the Co- and Momodified electrodes. Simultaneously, for larger overpotential values, the reaction system (not presented in Figure 3) moved into the mass transport limitations (see e.g., Ref. [27]). Pre-electrooxidation of Ni foam surfaces proved to be necessary to increase an initial value of the $j_{0}$ parameter for low overpotential range, as compared to an analogous Ni foambased electrode by $3.6 \times$ [23]. Additionally, such-recorded exchange current-density was higher than that for other $\mathrm{Ni}$ foam [24] and similar 3D-structured [25] Ni electrodes by $7.0 \times$ and $1.6 \times$, respectively. Moreover, as compared to similar catalysts [25], Mo-modified $\mathrm{Ni}$ foam electrode exhibited superior OER catalytic activity (with over $17 \times$ higher value of the $j_{0}$ parameter) to that of Ni-Mo composite coating.

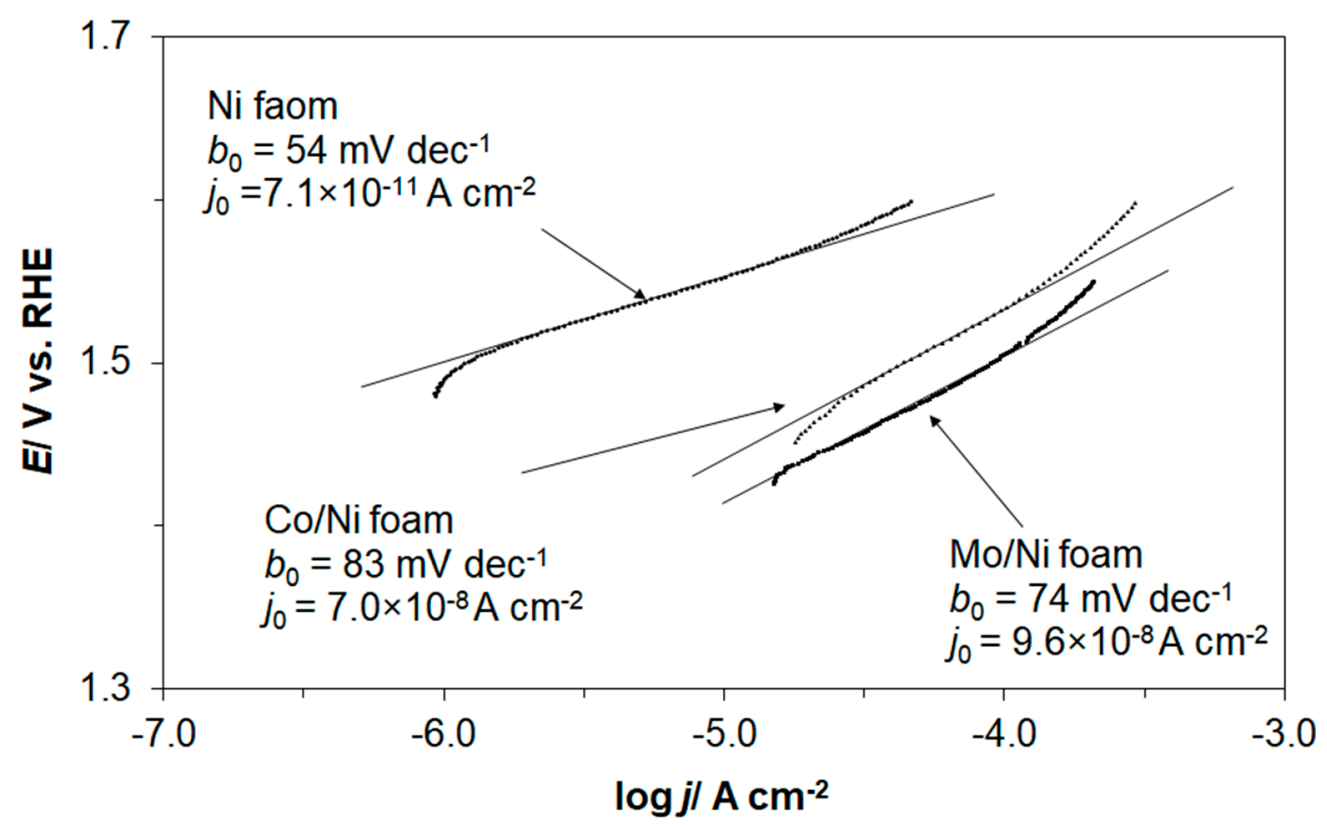

Figure 3. Quasi-potentiostatic anodic Tafel polarization curves (recorded at a scan-rate of $0.5 \mathrm{mV} \mathrm{s}^{-1}$ ) for oxidized Ni foam, Co- and Mo-activated Ni foam electrodes, carried out in $0.1 \mathrm{M} \mathrm{NaOH}$ solution (appropriate iR corrections were made based on the solution resistance derived from impedance measurements); calculated Tafel slopes for oxidized Ni foam, Co- and Mo-modified Ni foam samples came to $b_{\mathrm{a}}=54,83$ and $74 \mathrm{mV} \mathrm{dec}^{-1}$, correspondingly.

Nowadays, there is a trend in literature to show the Tafel polarization results for a set overpotential, typically at $\eta=0.300 \mathrm{~V}$ or a set current-density, usually at $10 \mathrm{~mA} \mathrm{~cm}{ }^{-2}[26,27]$. Hence, the current densities at $\eta=0.3 \mathrm{~V}$ for the Co-modified $\mathrm{Ni}$ foam electrode came to $9.2 \times 10^{-5} \mathrm{~A} \mathrm{~cm}^{-2}$, which was superior to those recorded in literature for various cobaltmodified anodes (see e.g., the recorded values of $1.4 \times 10^{-6}-1.0 \times 10^{-5} \mathrm{~A} \mathrm{~cm}^{-2}$ for cobalt oxide electrodes by Lyons and Brandon in Ref. [28]. On the other hand, the recorded $b_{\mathrm{a}}$ parameter for the examined electrodes was similar to those derived on Co and Mo modified 3D-structured electrodes ( 39 to $80 \mathrm{mV} \mathrm{dec}^{-1}$ ) by Kubisztal and Budniok, Badruzzaman et al. and Lyons, and Brandon in References [25-27].

In order to further characterize the electrocatalytic properties of $\mathrm{Ni}$ foam-based electrodes towards the OER, the electrochemical impedance spectroscopy (EIS) technique was applied. The complex-plane EIS spectra are shown in Figure 4. It should be mentioned that all electrodes have exhibited two somewhat depressed semicircles, where the high-frequency arc could be associated with the kinetics of the oxygen evolution reaction (interfacial charge-transfer reaction step). In contrast, the intermediate/low-frequency semicircle corresponds to the surface adsorption of the reaction intermediates [29-34]. The electrochemical parameters [Faradic reaction resistance $\left(R_{\mathrm{ct}}\right)$, the adsorption resistance 
for reaction intermediates $\left(R_{\text {Ads }}\right)$, double-layer capacitance $\left(C_{\mathrm{dl}}\right)$ and pseudo-capacitance $\left.\left(C_{\text {Ads }}\right)\right]$ were obtained by means of two constant phase element (CPE)-modified Randles equivalent circuit model (Figure 5), and their values are presented in Table 2. The CPE element was used within the circuit in order to account for the capacitance dispersion effect, represented by distorted semicircles in the Nyquist impedance plots.

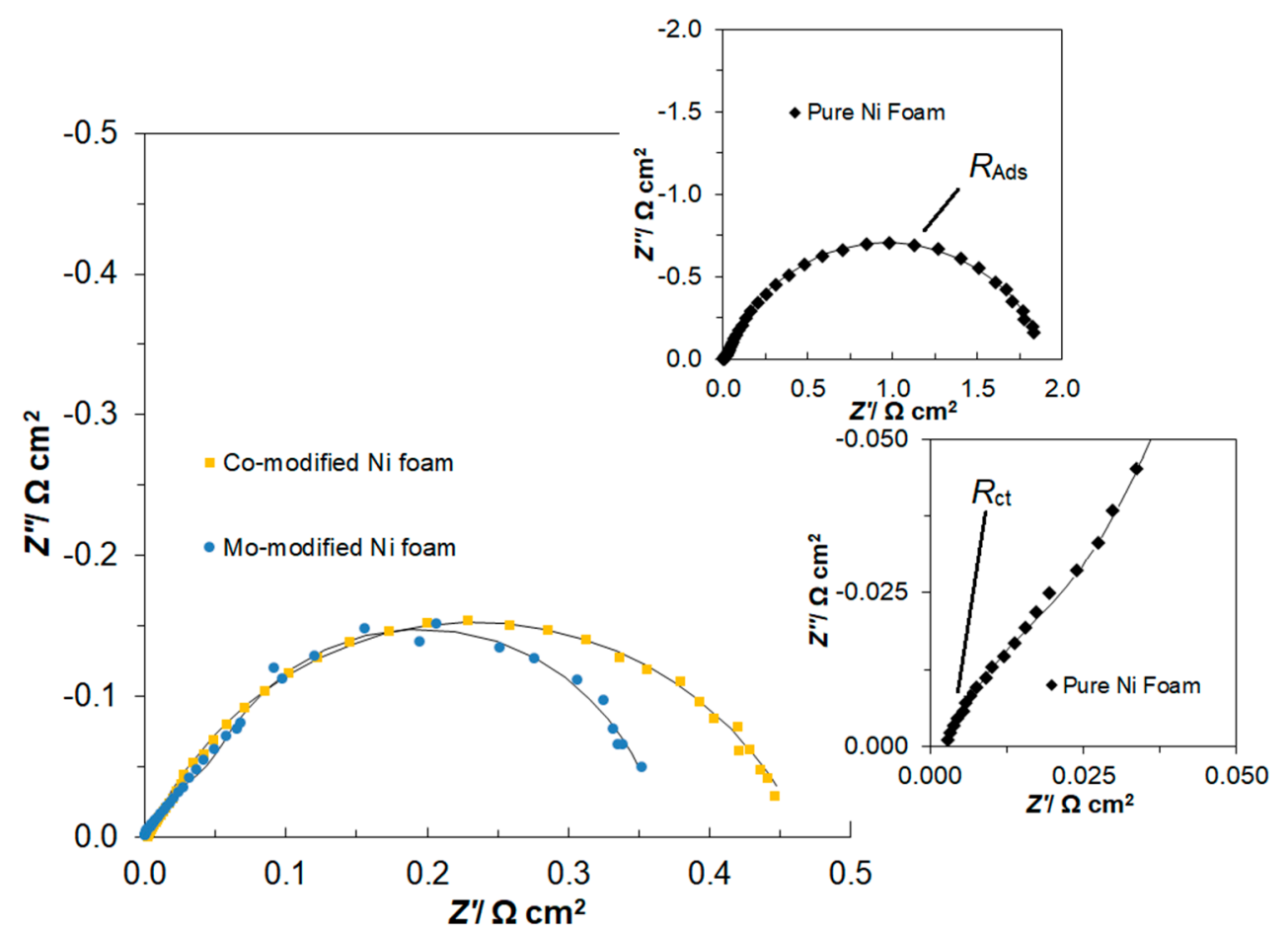

Figure 4. Electrochemical impedance Nyquist plots for the OER on oxidized Ni foam, Co- and Mo-modified Ni foam electrode surfaces in contact with $0.1 \mathrm{M} \mathrm{NaOH}$ (at $20^{\circ} \mathrm{C}$ ) for the potential of $1.6 \mathrm{~V}$ vs. RHE. The solid line corresponds to representation of the data according to equivalent circuit presented in Figure 5 below.

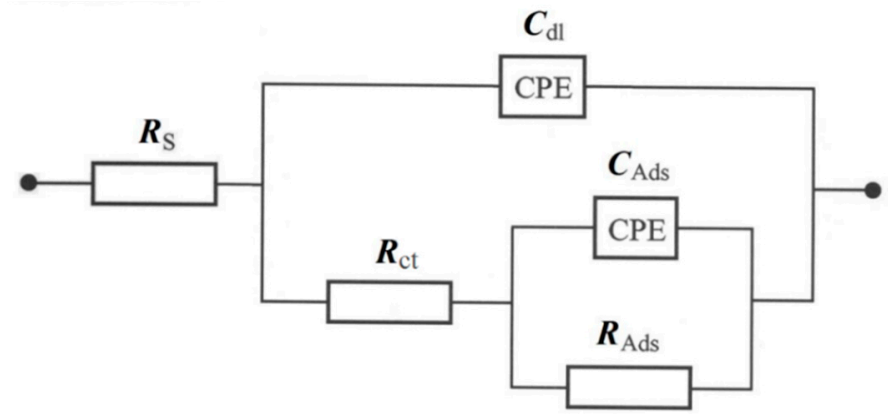

Figure 5. Equivalent circuit for impedance analysis of the OER process. Two CPE-R element equivalent circuit was used for fitting the impedance data for as received Ni foam, Co- and Moactivated $\mathrm{Ni}$ foam electrodes, obtained in $0.1 \mathrm{M} \mathrm{NaOH}$ solution. The circuit includes two constant phase elements (CPEs), to account for distributed capacitance; $R_{\mathrm{ct}}, C_{\mathrm{dl}}, R_{\mathrm{Ads}}$, and $C_{\mathrm{Ads}}$ (as CPE) elements correspond to the charge-transfer resistance, interfacial double-layer capacitance, resistance and capacitance adsorption components of reaction intermediates; $R_{\mathrm{S}}$ is solution resistance.

Thus, for the oxidized Ni foam electrode, the recorded $R_{\mathrm{ct}}$ parameter diminished from $0.187 \Omega \mathrm{g}$ to $0.047 \Omega \mathrm{g}$ at $\eta=270$ and $620 \mathrm{mV}$, respectively. Similarly, the $C_{\mathrm{dl}}$ parameter decreased from the value of 120,933 to reach $8720 \mu \mathrm{F} \mathrm{g}^{-1} \mathrm{~s}^{\varphi 1-1}$ for the same overpotential span (see Table 2 for details). The above effect could be associated with substantial blocking of the electrode surface by freshly formed $\mathrm{O}_{2}$ bubbles, which could easily be visually 
noticed, especially at increased anodic overpotentials. Simultaneously, the value of the $R_{\text {Ads }}$ parameter reduced from 41.756 to $0.123 \Omega \mathrm{g}$ for the corresponding potential range, while the $C_{\text {Ads }}$ parameter oscillated between an initial value of 144,293 (at $270 \mathrm{mV}$ ) and a minimum value of $67,867 \mu \mathrm{F} \mathrm{g}^{-1} \mathrm{~s}^{\varphi 2-1}$ recorded at $420 \mathrm{mV}$. The latter understandably implies that the kinetics of the OER become facilitated upon the rise of the dc electrode potential. However, the $R_{\text {Ads }}$ parameter values shown in Table 2 are essentially larger than those recorded for the $R_{\mathrm{ct}}$ parameter. The above suggests that the OER process is limited by the reaction intermediates' adsorption kinetics (also see References [23,34]).

Table 2. Electrochemical parameters for the OER, obtained at as received Ni foam, Co- and Mo-modified Ni foam electrodes in contact with $0.1 \mathrm{M} \mathrm{NaOH}$ supporting solution. The results obtained here were recorded by fitting the CPE-modified Randles equivalent circuit (see Figure 5) to the experimentally obtained impedance data (reproducibility usually below $10 \%$, $\chi^{2}=4.03 \times 10^{-5}$ to $1.07 \times 10^{-3}$.

\begin{tabular}{|c|c|c|c|c|}
\hline$\eta / \mathrm{mV}$ & $R_{\mathrm{ct}} / \Omega \mathrm{g}$ & $C_{\mathrm{d} 1} / \mu \mathrm{Fg}^{-1} \mathrm{~s}^{\varphi 1-1}$ & $R_{\mathrm{Ads}} / \Omega \mathrm{g}$ & $C_{\mathrm{Ads}} / \mu \mathrm{Fg}^{-1} \mathrm{~s}^{\varphi 2-1}$ \\
\hline \multicolumn{5}{|c|}{ Ni Foam } \\
\hline 270 & $0.187 \pm 0.033$ & $120,933 \pm 12,554$ & $41.756 \pm 4.524$ & $144,293 \pm 11,985$ \\
\hline 320 & $0.129 \pm 0.025$ & $127,147 \pm 12,430$ & $9.047 \pm 0.206$ & $103,520 \pm 11,383$ \\
\hline 370 & $0.073 \pm 0.008$ & $114,453 \pm 6488$ & $1.844 \pm 0.105$ & $81,360 \pm 5257$ \\
\hline 420 & $0.086 \pm 0.008$ & $89,627 \pm 3612$ & $0.616 \pm 0.008$ & $67,867 \pm 2587$ \\
\hline 470 & $0.075 \pm 0.007$ & $81,493 \pm 3352$ & $0.289 \pm 0.007$ & $73,840 \pm 3282$ \\
\hline 520 & $0.061 \pm 0.005$ & $67,600 \pm 3119$ & $0.176 \pm 0.005$ & $90,933 \pm 3627$ \\
\hline 570 & $0.064 \pm 0.005$ & $76,773 \pm 2646$ & $0.114 \pm 0.005$ & $78,717 \pm 5113$ \\
\hline 620 & $0.047 \pm 0.002$ & $8720 \pm 414$ & $0.123 \pm 0.003$ & $129,227 \pm 9950$ \\
\hline \multicolumn{5}{|c|}{ Co-modified Ni foam } \\
\hline 270 & $0.052 \pm 0.006$ & $541,047 \pm 15,371$ & $5.265 \pm 0.417$ & $670,980 \pm 28,526$ \\
\hline 320 & $0.035 \pm 0.004$ & $224,899 \pm 26,583$ & $1.239 \pm 0.009$ & $690,541 \pm 6229$ \\
\hline 370 & $0.030 \pm 0.004$ & $218,716 \pm 10,076$ & $0.217 \pm 0.004$ & $412,736 \pm 7235$ \\
\hline 420 & $0.027 \pm 0.003$ & $188,682 \pm 8730$ & $0.214 \pm 0.004$ & $444,831 \pm 6886$ \\
\hline 470 & $0.028 \pm 0.003$ & $141,993 \pm 5113$ & $0.128 \pm 0.003$ & $475,169 \pm 10,406$ \\
\hline 520 & $0.024 \pm 0.002$ & $121,588 \pm 3725$ & $0.089 \pm 0.002$ & $488,446 \pm 13,374$ \\
\hline 570 & $0.024 \pm 0.002$ & $161,622 \pm 5287$ & $0.052 \pm 0.002$ & $576,419 \pm 31,772$ \\
\hline 620 & $0.022 \pm 0.004$ & $105,473 \pm 9599$ & $0.041 \pm 0.005$ & $557,230 \pm 91,804$ \\
\hline \multicolumn{5}{|c|}{ Mo-modified Ni foam } \\
\hline 270 & $0.081 \pm 0.011$ & $822,987 \pm 85,015$ & $2.274 \pm 0.052$ & $1,743,525 \pm 143,562$ \\
\hline 320 & $0.069 \pm 0.010$ & $540,724 \pm 66,936$ & $0.667 \pm 0.018$ & $1,916,698 \pm 61,430$ \\
\hline 370 & $0.066 \pm 0.009$ & $599,202 \pm 157,063$ & $0.296 \pm 0.007$ & $1,680,668 \pm 168,453$ \\
\hline 420 & $0.068 \pm 0.017$ & $1,024,082 \pm 152,342$ & $0.181 \pm 0.014$ & $1,045,659 \pm 157,476$ \\
\hline 470 & $0.052 \pm 0.004$ & $200,204 \pm 20,927$ & $0.150 \pm 0.006$ & $1,512,226 \pm 94,060$ \\
\hline 520 & $0.035 \pm 0.008$ & $783,766 \pm 74,144$ & $0.111 \pm 0.008$ & $1,337,607 \pm 118,659$ \\
\hline 570 & $0.030 \pm 0.011$ & $1,008,571 \pm 140,070$ & $0.091 \pm 0.011$ & $916,327 \pm 126,682$ \\
\hline 620 & $0.023 \pm 0.003$ & $1,271,429 \pm 181,585$ & $0.087 \pm 0.003$ & $1,524,620 \pm 324,842$ \\
\hline
\end{tabular}

Then, the $R_{\mathrm{ct}}$ parameter for the Co and Mo-modified Ni foam electrodes ranged from 0.052 to $0.022 \Omega \mathrm{g}$ and from 0.081 to $0.023 \Omega \mathrm{g}$ for the overpotential range: $270-620 \mathrm{mV}$, respectively. The former implies a considerable reduction of the $R_{\mathrm{ct}}$ parameter (as compared to those $R_{\mathrm{ct}}$ values recorded for the oxidized $\mathrm{Ni}$ foam surface); namely, by $3.6 \times$ and $2.3 \times$ at $270 \mathrm{mV}$, and by $2.1 \times$ at $620 \mathrm{mV}$ for the Co and Mo-modified catalyst materials, respectively (see again Table 2 for details). Similarly, changing radius of the low-frequency semicircle (adsorption of reaction intermediates response) also resulted in a relatively constant decrease of the $R_{\text {Ads }}$ parameter value by ca. $8 \times$ and $3 \times$ for the cobalt-based, and by $18 \times$ and $1.4 \times$ for the Mo-modified Ni foam electrodes for the overpotentials of 270 and $620 \mathrm{mV}$.

Furthermore, deposition of catalytic nanostructures (see Figure 1a,b) resulted in a considerable enhancement of the electrochemically accessible surface area. The latter could be easily observed in the cyclic voltammetry plot presented for the baseline and 
the Co and Mo-modified Ni foam materials in Figure 2. Consequently, significant surface modification for the Co- and Mo-modified Ni foams is demonstrated by considerably increased current-density within the corresponding CV profiles.

The reported values of the $C_{\mathrm{dl}}$ parameter at $\eta=270 \mathrm{mV}$ came to $541,047 \mu \mathrm{F} \mathrm{g}^{-1} \mathrm{~s}^{\varphi 1-1}$ (Co-modified Ni foam) and 822,987 $\mu \mathrm{F} \mathrm{g}^{-1} \mathrm{~s}^{\varphi 1-1}$ for the Mo-based Ni foam catalyst material, which translates to ca. $4.5 \times$ and $6.8 \times$ augmentation of the HASA values for both modified electrodes, in contrast to the oxidized Ni foam anode. Once these surface coefficients are referred to the previously calculated ratios of the $R_{\text {ct }}$ parameter, it becomes evident that the cobalt-activated nickel foam anode exhibited superior OER performance. In addition, dimensionless $\varphi_{1}$ and $\varphi_{2}$ parameters (where $\varphi$ determines the constant phase angle in the complex-plane plot and $0 \leq \varphi \leq 1$ ) of the CPE circuits (see Figure 5) oscillated between: $0.66-0.97$ and $0.49-0.97$, respectively.

The impedance results obtained for the examined electrodes in this work were generally in line with those OER impedance studies presented by Si et al. [35] and by Lyons, and Brandon [28] on cobalt oxide electrodes, and by Choi et al. [36] and by $\mathrm{Wu}$, and $\mathrm{He}$ [37] on Mo-based composites. Moreover, Table 3 presents a comparison of the impedance-recorded $R_{\mathrm{ct}}$ and $j$ (polarization plot-estimated for $\eta=0.3 \mathrm{~V}$ ) parameter values in this work (the charge-transfer resistance was derived through the $C_{\mathrm{dl}}$-approximated surface area of the nickel foam electrodes $[23,38,39]$ ) with the results recorded on similar electrodes in References [35-37]. It should be noted that the $R_{\mathrm{ct}}$ results presented for Ni-Mo based electrodes in Refs. [36,37] were given as raw data, without providing any specific information on the electrodes' surface area. Thus, in order to make a meaningful comparison, one could estimate the HASA values through dividing the recorded interfacial capacitance by a commonly used value of $20 \mathrm{mF} \mathrm{cm}{ }^{-2}$ in literature for smooth and homogeneous surfaces (see Refs. [38,39]). Having done so, the surface-normalized $R_{\text {ct }}$ parameter would come to 981 and $364 \Omega \mathrm{cm}^{2}$ for Ni-Fe-C-Mo and $\mathrm{NiMoO}_{4}$ electrode surfaces, correspondingly. These estimated resistance values are radically greater than those recorded in this work. In addition, the plot-derived value of the $j$ parameter $\left(1.15 \times 10^{-5} \mathrm{~A} \mathrm{~cm}^{-2}\right)$ for Co oxide/Fe electrode came very close to the current-densities recorded in this work.

Table 3. Electrochemical parameters for the OER performed at the surfaces of different catalyst materials, under alkaline conditions.

\begin{tabular}{|c|c|c|c|c|c|}
\hline$\eta / \mathrm{mV}$ & Solution & Catalysts & $R_{\mathrm{ct}} / \Omega \mathrm{cm}^{2}$ & $j_{(\eta=0.3 \mathrm{~V})} / \mathrm{A} \mathrm{cm}^{-2}$ & Ref. \\
\hline 270 & $0.1 \mathrm{M} \mathrm{NaOH}$ & Co-modified Ni foam & 31.9 & $9.2 \times 10^{-5}$ & This work \\
\hline 420 & $0.1 \mathrm{M} \mathrm{NaOH}$ & Co-modified Ni foam & 16.6 & - & This work \\
\hline 430 & $0.1 \mathrm{M} \mathrm{KOH}$ & $\mathrm{Co}(\mathrm{OH})_{2} / \mathrm{C}$ & 8.5 & - & 35 \\
\hline 420 & $0.1 \mathrm{M} \mathrm{NaOH}$ & Co oxide/Fe & 17.5 & $1.15 \times 10^{-5}$ & 28 \\
\hline 270 & $0.1 \mathrm{M} \mathrm{NaOH}$ & Mo-modified Ni foam & 27.1 & $1.6 \times 10^{-4}$ & This work \\
\hline 420 & $0.1 \mathrm{M} \mathrm{NaOH}$ & Mo-modified Ni foam & 22.6 & - & This work \\
\hline 290 & $1.0 \mathrm{M} \mathrm{KOH}$ & $\mathrm{NiMoO}_{4}$ nanowire/Ni foam & $981 *$ & - & 36 \\
\hline 210 & $30 \% \mathrm{KOH}$ & $\mathrm{Ni}-\mathrm{Fe}-\mathrm{C}-\mathrm{Mo} / \mathrm{Ni}$ mesh & $364 *$ & - & 37 \\
\hline 438 & $1.0 \mathrm{M} \mathrm{NaOH}$ & $\mathrm{Pt}$ & 80 & $\sim 4 \times 10^{-5 * *}$ & 40 \\
\hline 278 & $0.1 \mathrm{M} \mathrm{KOH}$ & $\mathrm{RuO}_{2} / \mathrm{GC}^{* * *}$ & $142 *$ & $\sim 5 \times 10^{-4 * *}$ & 41 \\
\hline 250 & $0.1 \mathrm{M} \mathrm{KOH}$ & $\mathrm{Pd} / \mathrm{FTO}^{* * * *}$ & $42 *$ & $\sim 12 \times 10^{-3 * *}$ & 42 \\
\hline
\end{tabular}

${ }^{*}$ surface-normalized values (see information below); ${ }^{* *}$ values estimated from the Tafel plots; ${ }^{* * *}$ glassy carbon; ${ }^{* * * *}$ fluorine-doped tin oxide.

Furthermore, in order to fully access the suitability (and possibly also superiority) of the developed electrodes for their possible commercial use, Table 3 also presents the $R_{\mathrm{ct}}$ and $j(\eta=0.3 \mathrm{~V})$ parameter values for the OER, obtained on selected noble metals/oxide $\left(\mathrm{Pt}, \mathrm{RuO}_{2}\right.$ and $\left.\mathrm{Pd}\right)$, under similar experimental conditions [40-42]. Hence, the recorded (or estimated) charge-transfer resistance parameter values for bulk $\mathrm{Pt}, \mathrm{RuO}_{2} / \mathrm{GC}$ and $\mathrm{Pd} / \mathrm{FTO}$ electrodes were significantly greater than those recorded for the Co (or Mo)-modified nickel foam specimens. On the other hand, only fluorine-doped tin oxide palladium 
electrode exhibited radically higher values (ca. $12 \times 10^{-3} \mathrm{~A} \mathrm{~cm}^{-2}$ ) of Tafel plot-derived current-density parameter than those recorded in the present work for the catalyst $(\mathrm{Co}$, Mo)-modified nickel foam materials.

In addition, the exchange current-density values $\left(j_{0}\right)$ for the OER recorded for Co- and Mo-modified Ni foam samples were calculated based on the linear dependence of -log $R_{\mathrm{ct}} \mathrm{vs}$. overpotential $/ \eta$, fulfilled by kinetically controlled reactions through employing the Butler-Volmer equation and the relation between the $j_{0}$ and the $R_{\mathrm{ct}}$ parameter for overpotential approaching $0[43,44]$. Hence, the impedance-based exchange current-density value for the studied overpotential range $(\eta=270-620 \mathrm{mV}$ with $50 \mathrm{mV}$ potential increments) came to $6.06 \times 10^{-5} \mathrm{~A} \mathrm{~cm}^{-2}$ for the as-received $\mathrm{Ni}$ foam sample. However, significantly higher values of the $j_{0}$ parameter were recorded for both Co- and the Mo-modified Ni foam samples, i.e., $2.89 \times 10^{-4} \mathrm{~A} \mathrm{~cm}^{-2}$ and $1.04 \times 10^{-4} \mathrm{~A} \mathrm{~cm}^{-2}$, correspondingly (see Figure 6 below). In addition, the $R_{\mathrm{ct}}$-derived exchange-current densities are somewhat higher in comparison to those of other OER works performed on electrodes modified by $\mathrm{Co}$ and Mo elements in alkaline solutions $[25,45]$. There, the exchange current-density values recorded for $\mathrm{Ni}+$ Mo composite coating came to $9.7 \times 10^{-5} \mathrm{~A} \mathrm{~cm}^{-2}$ [25] and $5.2 \times 10^{-5} \mathrm{~A} \mathrm{~cm}^{-2}$ [45]. Similarly, values of the $j_{0}$ parameter, recorded for high overpotential range on Co-based compsite electrodes came to $3.5 \times 10^{-5} \mathrm{~A} \mathrm{~cm}^{-2}$ [46] and $1.1 \times 10^{-5} \mathrm{~A} \mathrm{~cm}^{-2}$ [28].

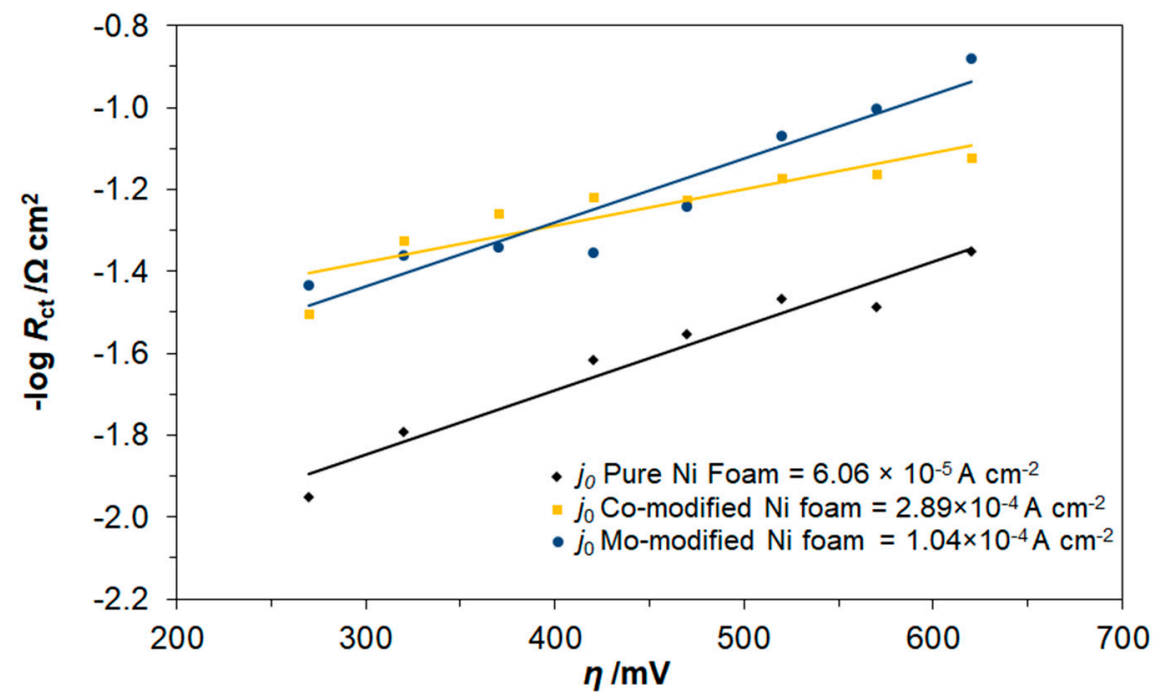

Figure 6. $-\log R_{\mathrm{ct}}$ vs. overpotential relationship for the OER on oxidized pure Ni foam, Co- and Mo-activated $\mathrm{Ni}$ foam electrode surfaces, carried-out in $0.1 \mathrm{M} \mathrm{NaOH}$ solution.

\section{Materials and Methods}

\subsection{Solutions and Chemical Reagents}

In this work, all supporting solutions were prepared by dissolving chemical reagents in ultra-pure water $(18.2 \mathrm{M} \Omega \mathrm{cm}$ ) from the Hydrolab (Spring $30 \mathrm{~s}$ ) purification system. $0.1 \mathrm{M} \mathrm{NaOH}$ working electrolyte was prepared from sodium hydroxide pellets $(99.996 \%$, AESAR, Ward Hill, NY, USA). Before each series of experiments, atmospheric air was removed from central and both side cell's compartments by bubbling with high purity argon (Ar 6.0 grade, Linde, Puławy, Poland) for 15 and $5 \mathrm{~min}$, respectively. Furthermore, argon gas flow was kept above the solutions throughout the experiments. $0.5 \mathrm{M} \mathrm{H}_{2} \mathrm{SO}_{4}$ (stock $\mathrm{H}_{2} \mathrm{SO}_{4}$ : $96 \%$, Merck, Darmstadt, Germany) solution was used for periodic charging of a Pd reversible hydrogen electrode (RHE).

\subsection{Preparation of Electrochemical Cell and Electrodes}

The OER activity of pure Ni foam, Co- and Mo-modified Ni foam electrodes was examined in an electrochemical cell made of Pyrex glass. The cell comprised three separate compartments. In the central compartment, a Ni foam-based working electrode (WE) was 
placed, when both Pd (1.0 mm diameter wire, $99.98+\%$ purity, AlfaAesar, Ward Hill, NY, USA) reversible hydrogen electrode and a Pt (1.0 mm diameter wire, $99.9998 \%$ purity, Johnson Matthey, Inc., London, UK) counter electrode (CE) were located in separate side compartments.

Nickel foam base electrode material was delivered by MTI Corporation (Richmond, CA, USA) (purity: $>99.99 \% \mathrm{Ni}$; thickness: $1.6 \mathrm{~mm}$; surface density: $346 \mathrm{~g} \mathrm{~m}^{-2}$; porosity: $\geq 95 \%$; estimated electrochemically active surface $14.9 \mathrm{~cm}^{2}$ ) [38]. All examined electrodes were $1 \mathrm{~cm} \times 1 \mathrm{~cm}$ (ca. $35 \mathrm{mg}$ ). Before electrodeposition of Co and Mo elements on Ni foam base material, freshly cut foam samples were degreased in acetone bath for $15 \mathrm{~min}$ under ultrasonication. Then, they were air dried and etched in $2 \mathrm{M} \mathrm{HCl}$ for $15 \mathrm{~min}$ at $60^{\circ} \mathrm{C}$, also under ultrasonication. Electrodeposition of $\mathrm{Co}$ and Mo catalysts on $\mathrm{Ni}$ foam was performed according to the conditions and bath compositions shown in Table 4. The bath's $\mathrm{pH}$ for Co electrodeposition was readjusted with $0.1 \mathrm{M} \mathrm{NaOH}$ or $0.1 \mathrm{M} \mathrm{HCl}$ solutions prior to the experiment. Similarly, before electrodeposition of Mo, the solution's $\mathrm{pH}$ was modified with $0.1 \mathrm{M} \mathrm{NaOH}$, accordingly. No significant $\mathrm{pH}$ change was observed during both metal deposition trials.

Table 4. Operating parameters and bath compositions employed for electrodeposition of Co and Mo onto Ni foam substrate.

\begin{tabular}{|c|c|c|}
\hline Bath Constituents & Concentration (M) & Operating Parameters \\
\hline \multicolumn{3}{|c|}{ Electrodeposition of Co } \\
\hline $\mathrm{CoCl}_{2} \times 6 \mathrm{H}_{2} \mathrm{O}(99 \%$, Sigma Aldrich, Saint Louis, MO, USA $)$ & 0.10 & Anode: Pt foil \\
\hline $\mathrm{NaCl}(99.9 \%, \mathrm{POCH}$, Gliwice, Poland) & 0.02 & $\begin{array}{c}\text { Cathode: Ni foam } \\
\text { Temperature: } 303 \mathrm{~K} \\
\text { Deposition time: } 300 \mathrm{~s} \\
\text { Current-density: } 0.52 \mathrm{~mA} \mathrm{~cm} \mathrm{~cm}^{-2} \\
\text { Solution pH: } 4.5\end{array}$ \\
\hline \multicolumn{3}{|c|}{ Electrodeposition of Mo } \\
\hline $\begin{array}{c}\left(\mathrm{NH}_{4}\right)_{6} \mathrm{Mo}_{7} \mathrm{O}_{24} \cdot 4 \mathrm{H}_{2} \mathrm{O}(\geq 99.3 \% \text {, Merck, Darmstadt, Germany }) \\
\mathrm{CH}_{3} \mathrm{CO}_{2} \mathrm{NH}_{4}(\geq 98.0 \% \text {, Merck, Darmstadt, Germany }) \\
\mathrm{CH}_{3} \mathrm{COOK}(\geq 99.0 \% \text {, Sigma Aldrich, Saint Louis, USA })\end{array}$ & $\begin{array}{l}1.95 \times 10^{-4} \\
0.26 \\
0.26\end{array}$ & $\begin{array}{c}\text { Anode: Pt foil } \\
\text { Cathode: Ni foam } \\
\text { Temperature: } 303 \mathrm{~K} \\
\text { Deposition time: } 1800 \mathrm{~s} \\
\text { Current density: } 5.2 \mathrm{~mA} \mathrm{~cm}{ }^{-2} \\
\text { Solution pH: } 6.8\end{array}$ \\
\hline
\end{tabular}

Such-modified Ni foam materials were left in a desiccator for an extended period of time before being weighed. Before conducting a series of electrochemical experiments, as received, Co- and Mo-modified Ni foam samples underwent extensive electrooxidation by means of 50 cyclic voltammetry sweeps, carried-out for the potential range 1.2-1.9 V/RHE, at a sweep rate of $50 \mathrm{mV} \mathrm{s}^{-1}$.

The palladium RHE was sealed in soft glass. Before its use, the reference electrode was cleaned in hot, concentrated sulphuric acid, followed by cathodic (galvanostatic) charging with hydrogen in $0.5 \mathrm{M} \mathrm{H}_{2} \mathrm{SO}_{4}$ until $\mathrm{H}_{2}$ bubbles in the electrolyte were clearly visible. The stability of such prepared RHE was occasionally checked by recording its potential shift in time (it should then be noted that all potentials throughout this work are given on the RHE scale). The CE electrode, prior to its use, was flame-annealed. Similarly, before each series of electrochemical experiments, the electrochemical cell was taken apart and soaked in hot sulphuric acid for at least $4 \mathrm{~h}$. After having been cooled to about $30^{\circ} \mathrm{C}$, the cell was thoroughly rinsed with Hydrolab ultra-pure water.

\subsection{Experimental Methodology}

Electrochemical performance of the OER electrocatalysts (pure Ni foam, Co-, and Mo-modified Ni foam electrodes) was conducted by a.c. impedance spectroscopy and quasi steady-state Tafel polarization techniques by means of an AUTM204 + FRA32M 
Multi-Autolab potentiostat/galvanostat system, at room temperature (293 K). For the a.c. impedance measurements, the generator provided an output signal of $5 \mathrm{mV} \mathrm{rms}$ and the frequency was swept between $1.0 \times 10^{5}$ and $2 \times 10^{-2} \mathrm{~Hz}$. The instruments were controlled by Nova 2.1 software for Windows (Metrohm Autolab B.V., Opacz-Kolonia, Poland). Also, all data analysis was performed with the above-mentioned software package. Typically, three impedance measurements were performed at each potential value, independently at two foam electrodes, where reproducibility of such obtained results was usually below $10 \%$. The obtained impedance spectra were fitted by means of a complex, nonlinear, leastsquares immittance fitting program. Furthermore, quasi-potentiostatic anodic polarization experiments (recorded at a scan-rate of $0.5 \mathrm{mV} \mathrm{s}^{-1}$ ) for the OER were carried-out at all $\mathrm{Ni}$ foam-based samples.

Additionally, SEM/EDX surface spectroscopy characterization of all examined (Ni foam, Co- and Mo-modified Ni foam) samples was carried out by means of Merlin FE-SEM microscope (Zeiss, Jena, Germany), equipped with Bruker XFlash 5010 EDX instrumentation (with $125 \mathrm{eV}$ resolution) (Bruker, Billerica, MA, USA).

\section{Conclusions}

Electrochemically deposited small amounts of transition metals in the form of cobalt (at $\sim 1$ wt.\%) and molybdenum (at $~ 0.28 \mathrm{wt} . \%$ ) nanoparticle deposits on the surface of Ni foam material significantly enhanced catalytic activity of the base foam material towards anodic evolution of oxygen in $0.1 \mathrm{M} \mathrm{NaOH}$ solution. The above is primarily related to superior OER catalytic properties of $\mathrm{Co}$ and Mo nano-deposits, in addition to the considerable modification of electrochemically-active surface for these catalyst materials. The results of this work showed a real possibility for replacing expensive and scarcely found in the natural environment noble metals with significantly cheaper transition metals for the mass production of commercial alkaline water electrolysers.

Author Contributions: Conceptualization, B.P.; methodology, B.P., M.Ł. and T.M.; investigation, M.Ł., M.K; data curation, T.M., M.L. and M.K.; writing-original draft preparation, M.Ł., T.M.; editing, B.P. and T.M.; supervision, I.M.K. All authors have read and agreed to the published version of the manuscript.

Funding: This work was financed by the research grant of the National Science Centre, Miniatura 1 project no. 2017/01/X/ST4/00881; Project financially supported by the Minister of Science and Higher Education in the range of the program entitled "Regional Initiative of Excellence" for the years 2019-2022, Project No. 010/RID/2018/19, amount of funding 12.000.000 PLN. The results in this paper were obtained as part of comprehensive study financed by the University of Warmia and Mazury in Olsztyn, Faculty of Agriculture and Forestry, Department of Chemistry (grant No. 30.610.001-110).

Acknowledgments: Mateusz Luba would also like to acknowledge a scholarship from the program Interdisciplinary Doctoral Studies in Bioeconomy (POWR.03.02.00-00-1034/16-00), funded by the European Social Fund.

Conflicts of Interest: The authors declare no conflict of interest.

\section{References}

1. Martins, F.; Felgueiras, C.; Smitkova, M.; Caetano, N. Analysis of Fossil Fuel Energy Consumption and Environmental Impacts in European Countries. Energies 2019, 12, 964. [CrossRef]

2. Krane, J. Climate change and fossil fuel: An examination of risks for the energy industry and producer states. MRS Energy Sustain. 2017, 4, 1-12. [CrossRef]

3. Dorning, M.A.; Diffendorfer, J.E.; Loss, S.R.; Bagstad, K.J. Review of indicators for comparing environmental effects across energy sources. Environ. Res. Lett. 2019, 14, 103002. [CrossRef]

4. Solarin, S.A. An environmental impact assessment of fossil fuel subsidies in emerging and developing economies. Environ. Impact Assess. Rev. 2020, 85, 106443. [CrossRef]

5. Kåberger, T. Progress of renewable electricity replacing fossil fuels. Glob. Energy Interconnect. 2018, 1, 48-52.

6. Wang, Q.; Chang, P.; Bai, R.; Liu, W.; Dai, J.; Tang, Y. Mitigation Strategy for Duck Curve in High Photovoltaic Penetration Power System Using Concentrating Solar Power Station. Energies 2019, 12, 3521. [CrossRef] 
7. Züttel, B.A.; Remhof, A.; Borgschulte, A.; Friedrichs, O. Hydrogen: The future energy carrier. Philos. Trans. R. Soc. Lond. Ser. A 2010, 358, 3329-3342. [CrossRef] [PubMed]

8. Khan, M.A.; Al-Shankiti, L.; Ziani, A.; Idriss, H. Demonstration of green hydrogen production using solar energy a $28 \%$ efficiency and evaluationof its economic viability. Sustain. Energy Fuels 2021, 5, 1085-1094. [CrossRef]

9. Dincer, I. Green methods for hydrogen production. Int. J. Hydrogen Energy 2012, 37, 1954-1971. [CrossRef]

10. Tahira, M.; Pana, L.; Idreesd, F.; Zhanga, X.; Wanga, L.; Zoua, J.J.; Wang, Z.L. Electrocatalytic oxygen evolution reaction for energy conversion and storage: A comprehensive review. Nano Energy 2017, 37, 136-157. [CrossRef]

11. Divanis, S.; Kutlusoy, T.; Boye, I.M.I.; Man, I.C.; Rossmeisl, J. Oxygen evolution reaction: A perspective on a decade of atomic scale simulations. Chem. Sci. 2020, 11, 2943-2950. [CrossRef]

12. Kuo, D.-Y.; Paik, H.; Kloppenburg, J.; Faeth, B.; Shen, K.M.; Schlom, D.G.; Hautier, G.; Suntivich, J. Measurements of Oxygen Electroadsorption Energies and Oxygen Evolution Reaction on $\mathrm{RuO}_{2}(110)$ : A Discussion of the Sabatier Principle and Its Role in Electrocatalysis. J. Am. Chem. Soc. 2018, 140, 17597-17605. [CrossRef] [PubMed]

13. Pérez-Viramontes, N.J.; Collins-Martínez, V.H.; Escalante-García, I.L.; Flores-Hernández, J.R.; Galván-Valencia, M.; Durón-Torres, S.M. Ir-Sn-Sb-O Electrocatalyst for Oxygen Evolution Reaction: Physicochemical Characterization and Performance in Water Electrolysis Single Cell with Solid Polymer Electrolyte. Catalysts 2020, 10, 524. [CrossRef]

14. Sanchez, J.; Ramos-Garcés, M.V.; Narkeviciute, I.; Colón, J.L.; Jaramillo, T.F. Transition Metal-Modified Zirconium Phosphate Electrocatalysts for the Oxygen Evolution Reaction. Catalysts 2017, 7, 132. [CrossRef]

15. Yuan, N.; Jiang, Q.; Li, J.; Tang, J. A review on non-noble metal based electrocatalysis for the oxygen evolution reaction. Arab. J. Chem. 2020, 13, 4294-4309. [CrossRef]

16. Dou, Y.; He, C.-T.; Zhang, L.; Al-Mamun, M.; Guo, H.; Zhang, W.; Xia, Q.; Xu, J.; Jiang, L.; Wang, Y.; et al. How Cobalt and Iron Doping Determine The Oxygen Exolution Electrocatalytic Activity of NiOOH. Cell Rep. Phys. Sci. 2020, 1, 1-14.

17. Milikić, J.; Balčiūnaitè, A.; Sukackienè, Z.; Mladenović, D.; Santos, D.M.F.; Tamašauskaitė-Tamašiūnaitė, L.; Šljukić, B. Bimetallic Co-Based (CoM, M = Mo, Fe, Mn) Coatings for High-Efficiency Water Splitting. Materials 2021, 14, 92. [CrossRef]

18. Kim, J.; Lee, D.H.; Yang, Y.; Chen, K.; Liu, C.; Kang, J.; Li, O.L. Hybrid Molybdenum Carbide/Heteroatom-Doped Carbon Electrocatalyst for Advanced Oxygen Evolution Reaction in Hydrogen Production. Catalysts 2020, 10, 1290. [CrossRef]

19. Wang, Y.; Wu, Q.; Zhang, B.; Tian, L.; Li, K.; Zhang, X. Recent Advances in Transition Metal Carbide Electrocatalysts for Oxygen Evolution Reaction. Catalysts 2020, 10, 1164. [CrossRef]

20. Ishaque, M.; Shah, A.; Iftikhar, F.J.; Akbar, M. Development of transition metal based electrolyzer for efficient oxygen evolution reaction. J. Renew. Sustain. Energy 2020, 12, 024102. [CrossRef]

21. Mikołajczyk, T.; Slis, A.; Solodovnik, T. Electrochemical Study of the Oxygen Evolution Reaction on MoNi/Carbon Fibre Electrode in $0.1 \mathrm{M} \mathrm{NaOH}$. Int. J. Electrochem. Sci. 2019, 14, 1773-1781. [CrossRef]

22. Chaudhari, N.K.; Jin, H.; Kim, B.; Lee, K. Nanostructured materials on 3D nickel foam as electrocatalysts for water splitting. Nanoscale 2017, 9, 12231-12247. [CrossRef] [PubMed]

23. Pierozynski, B.; Mikolajczyk, T.; Luba, M.; Zolfaghari, A. Kinetics of oxygen evolution reaction on nickel foam and platinummodified nickel foam materials in alkaline solution. J. Electroanal. Chem. 2019, 847, 113194. [CrossRef]

24. Van Drunen, J.; Pilapil, B.K.; Makonnen, Y.; Beauchemin, D.; Gates, B.D.; Jerkiewicz, G. Electrochemically Active Nickel Foams as Support Materials for Nanoscopic Platinum Electrocatalysts. ACS Appl. Mater. Interfaces 2014, 6, 12046-12061. [CrossRef]

25. Kubisztal, J.; Budniok, A. Study of the oxygen evolution reaction on nickel-based composite coatings in alkaline media. Int. J. Hydrogen Energy 2008, 33, 4488-4494. [CrossRef]

26. Badruzzaman, A.; Yuda, A.; Ashok, A.; Kumar, A. Recent advances in cobalt based heterogeneous catalysts for oxygen evolution reaction. Inorg. Chim. Acta 2020, 511, 119854. [CrossRef]

27. Lyons, M.E.; Brandon, M.P. A comparative study of the oxygen evolution reaction on oxidized nickel, cobalt and iron electrodes in base. J. Electroanal. Chem. 2010, 641, 119-130. [CrossRef]

28. Lyons, M.E.G.; Brandon, M.P. The Oxygen Evolution Reaction on Passive Oxide Covered Transition Metal Electrodes in Alkaline Solution. Part III-Iron. Int. J. Electrochem. Sci. 2008, 3, 1463-1503.

29. Doyle, R.L.; Lyons, M.E.G. An electrochemical impedance study of the oxygen evolution reaction at hydrous iron oxide in base. Phys. Chem. Chem. Phys. 2013, 15, 5224-5237. [CrossRef] [PubMed]

30. Lyons, M.E.G.; Brandon, M.P. The oxygen evolution reaction on passive oxide covered transition metal electrodes in aqueous alkaline solution. Part 1-nickel. Int. J. Electrochem. Sci. 2008, 3, 1386-1424.

31. Han, G.-Q.; Liu, Y.-R.; Hu, W.-H.; Dong, B.; Li, X.; Shang, X.; Chai, Y.-M.; Liu, Y.-Q.; Liu, C.-G. Three dimensional nickel oxides/nickel structure by in situ electro-oxidation of nickel foam as robust electrocatalyst for oxygen evolution reaction. Appl. Surf. Sci. 2015, 359, 172-176. [CrossRef]

32. Lyons, M.E.; Brandon, M.P. The significance of electrochemical impedance spectra recorded during active oxygen evolution for oxide covered $\mathrm{Ni}$, Co and Fe electrodes in alkaline solution. J. Electroanal. Chem. 2009, 631, 62-70. [CrossRef]

33. Costa, F.R.; Franco, D.V.; Da Silva, L.M. Electorchemical impedance spectroscopy study of the oxygen evolution reaction on a gas-evolving anode composed of lead dioxide microfibers. Electrochim. Acta 2013, 90, 332-343. [CrossRef]

34. Franco, D.V.; Da Silva, L.M.; Jardim, W.F.; Boodts, J.F.C. Influence of the electrolyte composition on the kinetics of the oxygen evolution reaction and ozone production processes. J. Braz. Chem. Soc. 2006, 17, 746-757. [CrossRef] 
35. Si, Y.; Guo, C.; Xie, C.; Xiong, Z. An Ultrasonication-Assisted Cobalt Hydroxide Composite with Enhanced Electrocatalytic Activity toward Oxygen Evolution Reaction. Materials 2018, 11, 1912. [CrossRef] [PubMed]

36. Choi, J.; Kim, D.; Zheng, W.; Yan, B.; Li, Y.; Yong, L.; Lee, L.Y.S.; Piao, Y. Interface engineered $\mathrm{NiFe}_{2} \mathrm{O}_{4-\mathrm{x}} / \mathrm{NiMoO}_{4} \mathrm{nanowire}$ arrays for electrochemical oxygen evolution. Appl. Catal. B Environ. 2021, 286, 119857. [CrossRef]

37. $\mathrm{Wu}, \mathrm{Y}$;; He, H. Electrodeposited nickel-iron-carbon-molybdenum film as efficient bifunctional electrocatalyst for overall water splitting in alkaline solution. Int. J. Hydrogen Energy 2019, 44, 1336-1344. [CrossRef]

38. Pierozynski, B.; Mikolajczyk, T.; Kowalski, I.M. Hydrogen evolution at catalytically-modified nickel foam in alkaline solution. J. Power Sources 2014, 271, 231-238. [CrossRef]

39. Pierozynski, B.; Mikolajczyk, T. On the Temperature Dependence of Hydrogen Evolution Reaction at Nickel Foam and PdModified Nickel Foam Catalysts. Electrocatalysis 2015, 6, 51-59. [CrossRef]

40. Cui, X.; Zhang, B.; Zeng, C.; Guo, S. Electrocatalytic activity of high-entropy alloys toward oxygen evolution reaction. MRS Commun. 2018, 8, 1230-1235. [CrossRef]

41. Kalimuthu, V.S.; Attias, R.; Tsur, Y. Electrochemical impedance spectra of $\mathrm{RuO}_{2}$ during oxygen evolution reaction studied by the distribution function of relaxation times. Electrochem. Commun. 2020, 110, 106641. [CrossRef]

42. Joya, K.S.; Ehsan, M.A.; Babar, N.-U.-A.; Sohail, M.; Yamani, Z.H. Nanoscale palladium as a new benchmark electrocatalyst for water oxidation at low overpotential. J. Mater. Chem. A 2019, 7, 9137-9144. [CrossRef]

43. Highfield, J.; Claude, E.; Oguro, K. Electrocatalytic synergism in Ni/Mo cathodes for hydrogen evolution in acid medium: A new model. Electrochim. Acta 1999, 44, 2805-2814. [CrossRef]

44. Shervedani, R.K.; Madram, A.R. Kinetics of hydrogen evolution reaction on nanocrystalline electrodeposited $\mathrm{Ni}_{62} \mathrm{Fe}_{35} \mathrm{C}_{3}$ cathode in alkaline solution by electrochemical impedance spectroscopy. Electrochim. Acta 2007, 53, 426-433. [CrossRef]

45. Plata-Torres, M.; Torres-Huerta, A.; Domínguez-Crespo, M.; Arce-Estrada, E.; Ramírez-Rodríguez, C. Electrochemical performance of crystalline $\mathrm{Ni}-\mathrm{Co}-\mathrm{Mo}-\mathrm{Fe}$ electrodes obtained by mechanical alloying on the oxygen evolution reaction. Int. J. Hydrogen Energy 2007, 32, 4142-4152. [CrossRef]

46. Hanumantrao, S.S.; Haram, S.K. Kinetic Analysis of the Oxygen Evolution Reaction (OER) Performed with a Cobalt-Phosphate Electrocatalyst. Chem. Sel. 2017, 2, 3323-3328. 